\title{
Isotherm study of banana stem waste adsorbents to reduce the concentration of textile dying waste
}

DOI:10.36909/jer.ASSEEE.16063

Asep Bayu Dani Nandiyanto ${ }^{1, *}$, Nissa Nur Azizah ${ }^{2}$, Salma Rahmadianti ${ }^{1}$,

${ }^{1}$ Departemen Kimia, ${ }^{2}$ Departemen Pendidikan Ilmu Komputer, Universitas Pendidikan Indonesia, Bandung, Indonesia.

*Email: nandiyanto@upi.edu; Corresponding Author.

\begin{abstract}
The purpose of this study was to make carbon from banana stem waste and determine the isotherm adsorption characteristics of carbon from banana stem waste to methyl orange compounds. The process for making carbon from banana stem waste was done through the stages of preparation and carbonization at a temperature of $250^{\circ} \mathrm{C}$ for $1.5 \mathrm{~h}$. Before being used as carbon, banana stem waste was cleaned, washed, dried, and mashed using a mill. The carbon then went through a washing process to remove impurities and tested for its absorbance ability into a solution containing a methyl orange compound under constant conditions of $\mathrm{pH}$, temperature, and pressure. The experimental results showed that the appropriate sequence of adsorption models is the Langmuir, Temkin, Freundlich, and Dubinin-Radushkevich models. Adsorption occurs on the surface of a single layer (monolayer) and the interaction between the adsorbent and the adsorbate occurs physically. The value of maximum adsorption capacity $\left(Q_{\max }\right)$ is $37.5940 \mathrm{mg} / \mathrm{g}$. The presence of banana stem carbon is expected to reduce the negative impacts, one of which is the disposal of industrial wastewater from textile factories.
\end{abstract}

Keywords: Banana Stem, Textile Dye, Model Isotherm, Methyl Orange, Carbon 


\section{INTRODUCTION}

Adsorption is one of the effective methods to remove toxic compounds in polluted liquids (Hayati et al., 2018). Several materials for adsorbents have been suggested, in which most of them utilized agricultural and plantation waste, including adsorbents from soursop peel (Nandiyanto et al., 2020), durian peel (Moelyaningrum et al., 2018), rice husks (Fiandini et al., 2020), Corncob (Wang et al., 2020), and Banana pseudo-stem (Ab Ghani et al., 2017). However, no report on the use of banana stem, while the use of banana stem is beneficial since it is largely available (Das et al., 2008). Venkateshwaran and Elayaperumal (2010) reported high levels of cellulose in the banana stem, reaching $46 \%$, followed by hemicellulose of $38.54 \%$ and lignin of $9 \%$. Cellulose has great potential to be used as an adsorbent because the presence of $\mathrm{OH}$ groups bound to cellulose when heated at high temperatures will release hydrogen and oxygen atoms only, making carbon materials can be obtained easily and porous (Zhou et al., 2017). The high cellulose content makes banana stem waste feasible as a raw material for carbon production.

The objective of our study was to produce carbon particles from the banana stem as the adsorbent. We also analyzed isotherm adsorption using the isotherm models of Langmuir, Freundlich, Temkin, and Dubinin-Radushkevich. This research can be useful to provide information on the use of alternative agricultural waste materials (i.e. banana stem) as an adsorbent to adsorb textile dyes.

\section{MATERIAL AND METHOD}

This study used four adsorption models (i.e. Langmuir, Freundlich, Temkin, and DubininRadushkevich isotherm models) to provide the adsorption relationship, in which the detailed information is in our previous study (Ragadhita et al., 2021). The adsorption efficiency $(\eta)$ is calculated using the initial concentration of adsorbate $(C o, \mathrm{mg} / \mathrm{L})$ and $C_{e}$ is the equilibrium 
adsorbate concentration ( $C e, \mathrm{mg} / \mathrm{L})$, as shown in equation (1):

$$
\eta=\left(\frac{C_{o}-C_{e}}{C_{o}}\right) \times 100 \%
$$

The Langmuir model helps qualitative analysis in the formation of a monolayer adsorption model on the outer surface of the adsorbent. When the adsorbate attaches to the surface of the adsorbent, there is no further adsorption process that occurs from other adsorbates (Langmuir, 1918). The adsorption isotherm model also assumes a homogeneous surface without interactions between adsorbate molecules. No transmigration occurs from the adsorbate during the adsorption process. Langmuir's model is shown in equations (2) and (3) (Chung et al., 2015).

$$
\begin{aligned}
\frac{1}{Q_{e}} & =\frac{1}{Q_{\max } K_{L}} \frac{1}{C_{e}}+\frac{1}{Q_{\max }} \\
R_{L} & =\frac{1}{1+K_{L} C_{e}}
\end{aligned}
$$

where $K_{L}$ is the Langmuir adsorption constant, $Q_{e}$ is the number of adsorbate molecules adsorbed per gram of adsorbent $(\mathrm{mg} / \mathrm{g})$, and $Q_{\max }$ is the capacity of the adsorbent monolayer (mg/g). The $R_{L}$ value is the adsorption factor (Ragadhita et al., 2019), in which the value confirms (i) $R_{L}>1$ (an unfavorable adsorption process (allows for adsorption to occur but mostly desorption occurs); (ii) $R_{L}=1$ (the linear adsorption process (adsorption isotherm depends on the amount and concentration of adsorbent)); (iii) $R_{L}=0$ (the irreversible adsorption process (the adsorption process is too strong)); and, $0<R_{L}<1$ (favorable adsorption process (adsorption can be controlled under certain conditions)).

The Freundlich isotherm adsorption model is the most widely used non-linear adsorption model, which expresses multilayer adsorption with heterogeneous energy distribution of the active plane on the adsorbent. This model also calculates the interactions between the adsorbed molecules. Multilayer adsorption can be applied to this isothermal model (Ragadhita 
et al., 2019). Freundlich's equation can be written by equation (4) as follows:

$$
\log Q_{e}=\log k_{f}+\frac{1}{n} \log C_{e}
$$

where $k_{f}$ is the Freundlich constant and $\mathrm{n}$ is the value indicating the intensity of adsorption. The value of $n$ means: (i) $n<1$ (chemical adsorption); (ii) $n=1$ (linear adsorption process (adsorption process depends on the amount and concentration adsorbed, can be a combination of chemical and physical adsorption processes)); (iii) $n>1$ (physical adsorption); (iv) $1 / n>1$ (cooperative adsorption); (v) $0<1 / n<1$ (favorable adsorbs (normal adsorption process)).

The Temkin model describes the relationship of the indirect interaction of the adsorbate and the adsorption isotherm. The heat of adsorption of all adsorbate molecules on the surface is the adsorbate-adsorbate interaction. This model explains the explicit factors in the adsorbate interaction. Assuming that the adsorbate concentration is very low, the heat of adsorption of all molecules is a function of temperature and is shown by the equation (5):

$$
Q_{e}=\beta_{T}\left(\ln C_{e}\right)+\left(\beta_{T} \ln A_{T}\right)
$$

where $A_{T}$ is the equilibrium constant in the Temkin isotherm model. $\beta_{T}$ is the Temkin isotherm constant, explaining that (i) $\beta_{T}<8 \mathrm{~kJ}$ (physical adsorption); and (ii) $\beta_{T}>8 \mathrm{~kJ}$ (chemical adsorption). The Temkin model also predicts the involvement of energy in the adsorption process in equation (6):

$\theta=\frac{R T}{\Delta Q} \ln \left(C_{e}\right)+\frac{R T}{\Delta Q} \ln \left(K_{T}\right)$

where $T$ is the temperature $(\mathrm{K})$ and $R$ is Boltzmann's constant $(8.314 \mathrm{~J} / \mathrm{mol} . \mathrm{K})$. is the fraction of components adsorbed on the surface of the adsorbent, which can be calculated by dividing the adsorbate adsorbed on the surface of the adsorbent by the total amount of initial concentration of adsorbate. $K_{T}$ is the energy constant $(\mathrm{L} / \mathrm{mg})$ in Temkin. $\Delta Q$ is the adsorption energy $(\mathrm{kJ} / \mathrm{mol})$. Assuming that the process occurs in a closed system, then the value of $\Delta Q$ is almost identical to that of heat $(\Delta H)$, resulting in the equation $(7)$ : 
$\Delta Q=-\Delta H$

The value of $\Delta H$ shows: $\Delta H>0 \mathrm{~kJ} / \mathrm{mol}$ is an endothermic process and $\Delta H<0 \mathrm{~kJ} / \mathrm{mol}$ is an exothermic process.

The Dubinin-Radushkevich model is generally used to regulate the adsorption mechanism on heterogeneous surfaces which is represented by the equation (8):

$$
\ln Q_{e}=\ln Q_{s}-\beta \varepsilon^{2}
$$

where $Q_{s}$ is the saturation capacity of the theoretical isotherm $(\mathrm{mg} / \mathrm{g}), \beta$ is the DubininRadushkevich isotherm constant associated with the mean free adsorption energy per mole of adsorbate and $\varepsilon$ is the Polanyi potential associated with equilibrium conditions. This model refers to the equations of equations (9) and 10):

$$
\begin{aligned}
& \varepsilon=R T \ln \left[1+\frac{1}{C_{e}}\right] \\
& E=\frac{1}{\sqrt{2 \beta}}
\end{aligned}
$$

where $E$ is the energy to predict the type of adsorption: $E<8 \mathrm{~kJ} / \mathrm{mol}$ is physical adsorption and $E>8 \mathrm{~kJ} / \mathrm{mol}$ is chemical adsorption.

Banana stem waste (obtained from local farmers in Bandung, Indonesia) was used for the preparation of banana stem carbon adsorbent. The adsorbent process is carried out by drying the waste banana stem waste under the light for 5 days and followed by solar carbonization using the electrical furnace (SHARP; Model EO-28LP(K), China) at $250^{\circ} \mathrm{C}$ for $1.5 \mathrm{~h}$. After the banana stems were transformed into carbonaceous, they are grounded using a sawmilling process. Carbon was obtained from a sieve using a mesh to produce carbon particle sizes of 250 and 500 micrometers. Each size with a weight of $2 \mathrm{~g}$ was put into a centrifuge and added distilled water. Carbon particles that have been shaken must be filtered using filter paper to separate the carbon from the solvent. The carbon contained in the filter paper is added with distilled water to make it cleaner and dried in the sun to dry completely. 
Determination of the adsorption characteristics of methyl orange dye using banana stem waste adsorbent was carried out by making a solution of methyl orange dye with a concentration of 20,30, and $50 \mathrm{ppm}$. Then measure the initial concentration of the solid in the methyl orange solution. 0.05 grams of banana stem waste carbon was added to the methyl orange solution at each concentration of $100 \mathrm{ml}$ and stirred with a stirring rod for 15 minutes. The stirred solution was filtered and the filtrate obtained was measured for its concentration using a portable e-1 TDS and EC meter to determine the final concentration of dissolved solids. The TDS meter was used since it was the simplest and practical tool to measure the concentration of a solution. Because methyl orange is reactive, the adsorption procedure was carried out at room temperature in a closed system to avoid light and oxidation. Only one experiment was carried out.

Data analysis used the parameters of the isotherm adsorption model to determine the adsorption characteristics. The adsorption parameters were searched using linear isotherm plotting for each model. The adsorption parameters of the Langmuir model were searched by connecting the graph between $1 / C_{e}$ to $1 / Q_{e}$. The adsorption parameters of the Freundlich model were obtained from the graph of the relationship between $\ln C_{e}$ and $\ln Q_{e}$, the Temkin model was obtained from the graph of the relationship between $\ln C_{e}$ and $C_{e}$. The adsorption parameters of the Dubinin-Radushkevich model were obtained from the graph of the relationship between $\varepsilon^{2}$ and $\ln Q_{e}$.

\section{RESULTS AND DISCUSSION}

Based on other previous studies regarding the adsorption process using banana stem are:

(i) Misran et al. (2021) showed that the best model for adsorbing methylene blue was the Freundlich isotherm model;

(ii) Rahim \& Haris (2019) showed the best model for the adsorption process for $\mathrm{Cr}^{6+}$ was the Freundlich model. 
(iii) Grace et al. (2020) showed that the best model for the adsorption process of $\mathrm{Pb}^{2+}$ was for the Langmuir model, and they showed the occurrence of the endothermic process; (iv) Mery et al. (2019) showed the use of carbonized banana stem of $56.97 \%$.

Figure 2 shows a linear plotting analysis of the relationship between the efficiency of the adsorbate concentration and the size variation of the carbon particles as adsorbents. The adsorption efficiency is affected by the size of the carbon particles. Particles with a smaller size have a higher adsorption efficiency value due to a larger surface area (YaghoobiKhankhajeh et al., 2018).

The results of the plotting analysis of the Langmuir, Freundlich, Temkin, and DubininRadushkevich models are shown in Figures 3, 4, 5, and 6, respectively. Detailed information about the parameters obtained from linear plotting is shown in Table 1.

Figure 3 (a) shows a linear plotting analysis using the Langmuir model. The Langmuir model assumes that the surface of the adsorbent is homogeneous and the interaction only occurs in a single adsorption layer (monolayer) (Langmuir, 1918). Langmuir parameters such as $R^{2}, Q_{\max }$, $R_{L}$ dan $K_{L}$ were determined from equations 2 and 3. Langmuir linear plotting showed that carbon particles with a size of 500 and $250 \mu \mathrm{m}$ had $R^{2}$ values of 0.9968 and 0.9984 , respectively (Table 1). These two sizes have the potential to form a monolayer structure (Nandiyanto et al., 2020, Zhou et al., 2017).

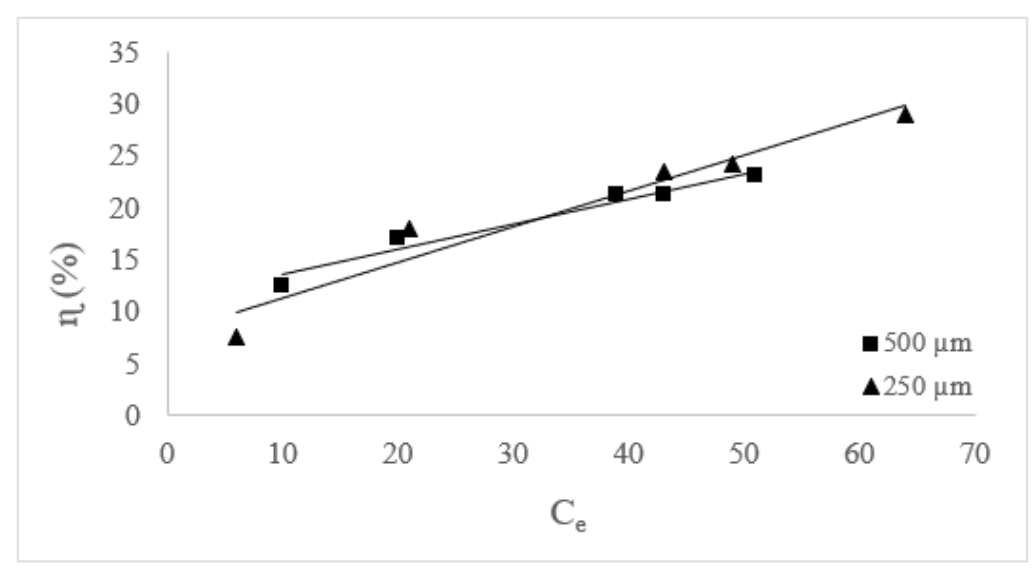

Figure 2. Linear plotting of the relationship between efficiency and adsorbate concentration. 
Table 1. Parameters of the adsorption isotherm model.

\begin{tabular}{|c|c|c|c|c|}
\hline \multirow{2}{*}{ Model } & \multirow{2}{*}{ Parameter } & \multicolumn{2}{|c|}{ Particle Size ( } & \multirow{2}{*}{ Note } \\
\hline & & 500 & 250 & \\
\hline \multirow[t]{4}{*}{ Langmuir } & $R^{2}$ & 0.9968 & 0.9984 & The correlation coefficient \\
\hline & $Q_{\max }(\mathrm{mg} / \mathrm{g})$ & 27.8552 & 37.5940 & $\begin{array}{l}\text { The maximum } \\
\text { monolayer adsorption } \\
\text { capacity }\end{array}$ \\
\hline & $K_{L}(\mathrm{~L} / \mathrm{mg})$ & 0.0809 & 0.0416 & $\begin{array}{l}\text { Langmuir adsorption } \\
\text { constant }\end{array}$ \\
\hline & $R_{L}$ & 0.3188 & 0.4589 & $\begin{array}{l}0<R_{L}<1, \text { favorable } \\
\text { adsorption }\end{array}$ \\
\hline \multirow[t]{4}{*}{ Freundlich } & $R^{2}$ & 0.9888 & 0.9816 & The correlation coefficient \\
\hline & $n$ & 2.7427 & 1.8008 & $\begin{array}{l}n>1, \text { adsorption with } \\
\text { physical process }\end{array}$ \\
\hline & $1 / n$ & 0.3646 & 0.5553 & $\begin{array}{l}1 / n=0-1, \text { favorable } \\
\text { adsorption }\end{array}$ \\
\hline & $K_{F}(\mathrm{mg} / \mathrm{g})$ & 5.5157 & 2.9209 & Freundlich constant \\
\hline \multirow[t]{3}{*}{ Temkin } & $R^{2}$ & 0.9934 & 0.9856 & The correlation coefficient \\
\hline & $\beta_{T}(\mathrm{~kJ} / \mathrm{mol})$ & 0.3955 & 0.2904 & $\begin{array}{l}\beta_{T}<8 \mathrm{~kJ} / \mathrm{mol}, \text { physical } \\
\text { adsorption }\end{array}$ \\
\hline & $A_{T}(\mathrm{~L} / \mathrm{g})$ & 0.7437 & 0.3906 & $\begin{array}{l}\text { The equilibrium binding } \\
\text { constant }\end{array}$ \\
\hline \multirow{3}{*}{$\begin{array}{l}\text { Dubinin- } \\
\text { Radushkevich }\end{array}$} & $R^{2}$ & 0.9373 & 0.9356 & The correlation coefficient \\
\hline & $\beta\left(\mathrm{mol}^{2} / \mathrm{kJ}^{2}\right)$ & 0.0105 & 0.0082 & $\begin{array}{l}\text { The Dubinin-Radushkevich } \\
\text { isotherm saturation } \\
\text { capacity }\end{array}$ \\
\hline & $E(\mathrm{~kJ} / \mathrm{mol})$ & 6.9007 & 7.8087 & $\begin{array}{l}E<8 \mathrm{~kJ} / \mathrm{mol} \text {, physical } \\
\text { adsorption }\end{array}$ \\
\hline
\end{tabular}

Based on Figure 3(a), the $R^{2}$ value for carbon particles with the Langmuir model is the highest when compared to the $R^{2}$ value for other models, this indicates that the adsorption of carbon particles is in accordance with the Langmuir model. The maximum capacity $\left(Q_{\max }\right)$ of the carbon particles will increase when using a smaller size carbon. Based on experimental data, the $R_{L}$ value ranges between 0 and 1, explaining that adsorption is favorable (Lairini et al., 2017) and this result is in accordance with Freundlich's model which also states that adsorption is favorable. 

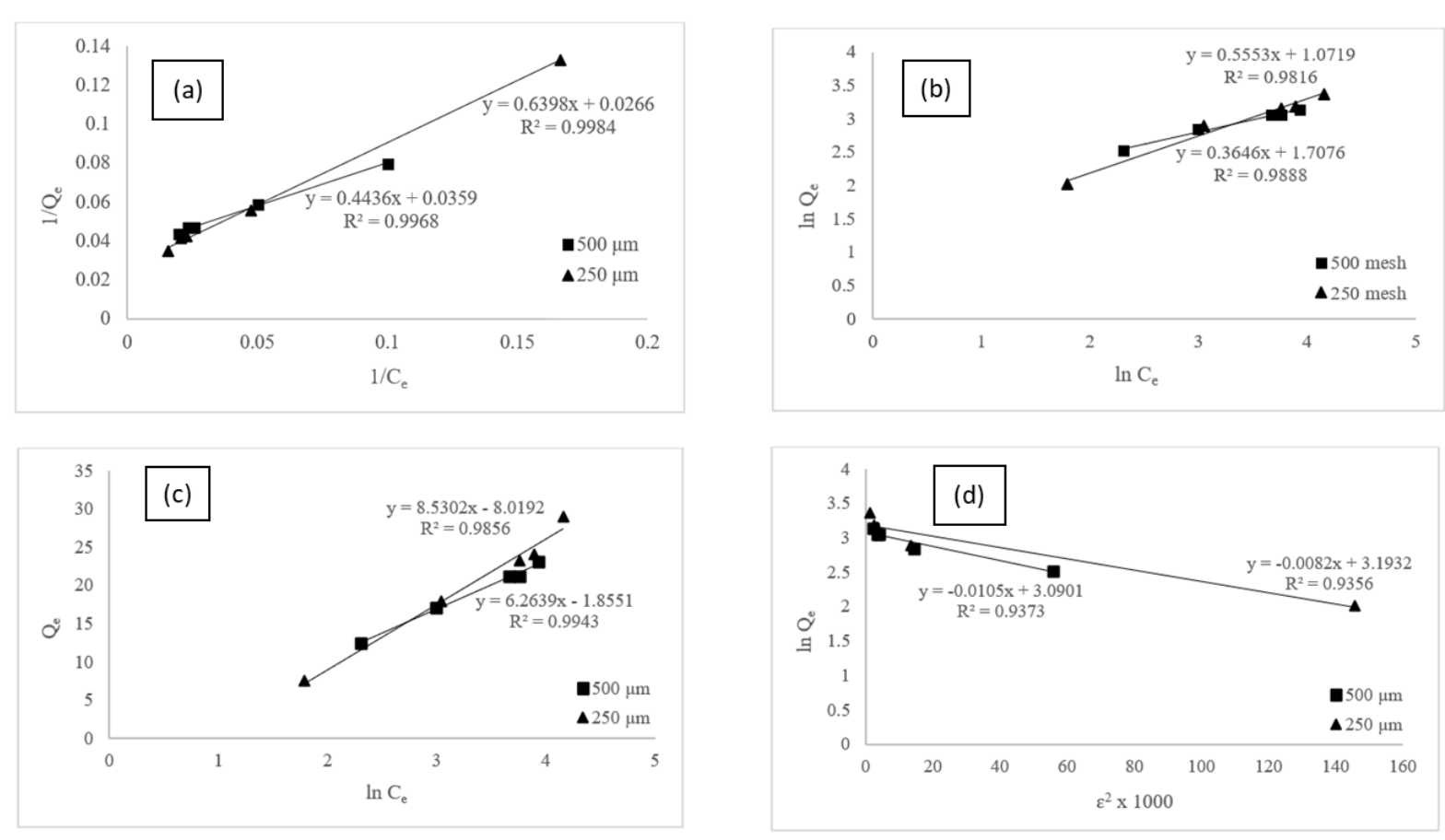

Figure 3. Linear plotting of isotherm adsorption model by banana stem waste carbon: (a)

Langmuir, (b) Freundlich, (c) Temkin, and (d) Dubinin-Radushkevich.

Figure 3 (b) shows a linear plotting analysis using the Freundlich model. Freundlich model parameters such as $R^{2}, n, 1 / n$, and $K_{F}$ values are obtained from equation 4 . Freundlich's linear plotting shows that carbon particles with a size of 500 and $250 \mu \mathrm{m}$ have $R^{2}$ values of 0.9888 and 0.9816 , respectively (Table 1). Based on the experiment, the value of $1 / n$ is between 0 to 1 explaining that the adsorption is favorable (Lairini et al., 2017, Ata et al., 2019). The value of $n$ obtained is more than 1, indicating that physical adsorption (physisorption) (Ata et al., 2019).

Figure 3 (c) shows the linear plotting analysis of the Temkin adsorption model. The Temkin model parameters such as $R^{2}, \beta_{T}$, and $A_{T}$ were obtained from equation 5. The $R^{2}$ values for 500 and $250 \mu \mathrm{m}$ were 0.9934 and 0.9856 , respectively the shows Table 1 The value of $\beta_{T}$ less than $8 \mathrm{~kJ} / \mathrm{mol}$ in the Temkin model indicates the occurrence of a physical adsorption process (Mahmoud et al., 2017, Kamga., 2019). This is in accordance with the results of Freundlich's analysis, namely that there is a physical adsorption process. 
Figure 3 (d) shows the linear plotting analysis of the Dubinin-Radushkevich isotherm. The Dubinin-Radushkevich model parameters such as $R^{2}, \beta$, and $E$ were obtained from formulas 810. The $R^{2}$ values for particle sizes of 500 and $250 \mu \mathrm{m}$ were obtained at 0.9373 and 0.9356 , respectively, shown in Table 1 . The Dubinin-Radushkevich model has the lowest $R^{2}$ value when compared to other models, so the adsorption of methyl dye using banana stem adsorbent is not suitable for this model. The value of $E$ for all particle sizes showed a value of less than $8 \mathrm{~kJ}$, indicating that the adsorption occurred physically (Dada et al., 2019, Hu \& Zhang., 2019). This result is in accordance with the Freundlich model and also Temkin which shows that the adsorption process occurs physically.

The adsorption analysis showed that the most suitable isotherm model based on the obtained $R^{2}$ value was the Langmuir model. Based on the data in Table 1, the most suitable sequence of isotherm models is Langmuir, Temkin, Freundlich, and Dubinin-Radushkevich. Figure 4 shows that based on research on carbon generation from banana stem waste, it shows that the adsorption process occurs on the surface of a single layer (monolayer) (Nandiyanto et al., 2020; Zhou et al., 2017), the interaction between the adsorbent and adsorbate occurs physically (physisorption) (Ata et al., 2019; Mahmoud et al., 2017; Kamga., 2019), and has a porous structure.

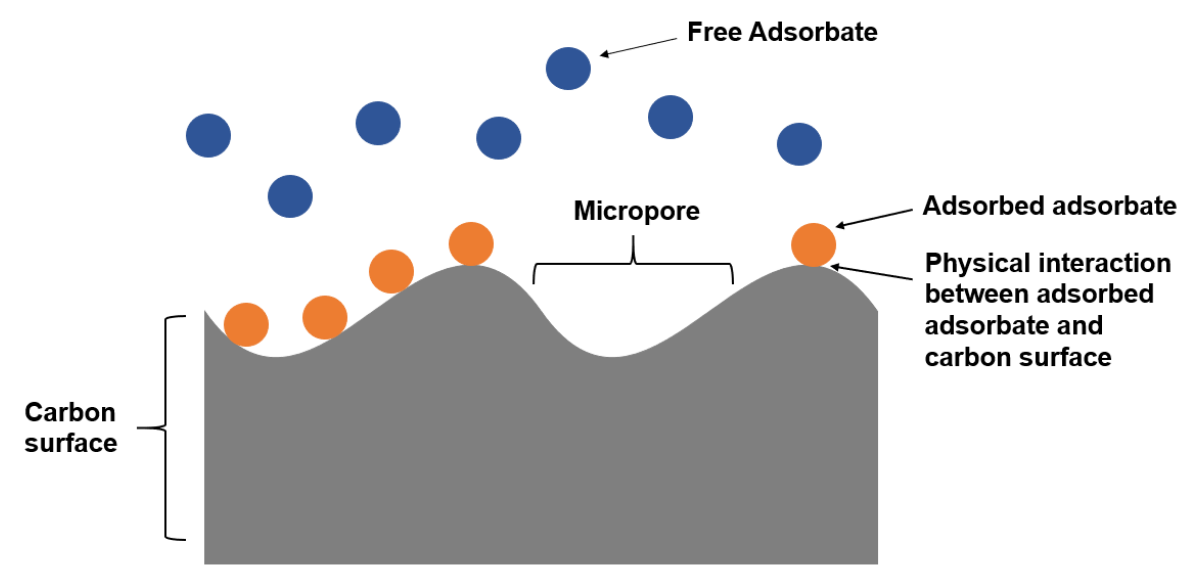

Figure 4. Monolayer adsorption model

The results showed that the adsorbent with a smaller size can increase the adsorption capacity 
due to the larger surface area. Theoretically, the particle size of the adsorbent affects the adsorption process. The adsorption capacity increases followed by a decrease in particle size. The surface area has an inverse relationship with particle size (Mishra et al., 2010). When the surface area of the carbon particles increases, the particle size decreases, causing the adsorption capacity $\left(Q_{\max }\right)$ to increase. In addition, particles with smaller sizes will be more optimal for the adsorption process because the aggregation between particles causes larger particles. When compared with other adsorbent materials, carbon from banana stems has a slightly lower ability than carbon from pumpkin seeds due to smaller porosity.

\section{CONCLUSION}

The analysis of carbon particle adsorption isotherm from banana stem waste has been successfully done. Based on the results of plotting data on Langmuir, Freundlich, Temkin, and Dubinin-Radushkevich adsorption models provide good correlations for all particle size cases and Langmuir is the best isotherm model in this study. This adsorption process takes place on one surface (monolayer), the adsorbent-adsorbate interaction is physical adsorption (physisorption) (which is confirmed with the results from Langmuir models and is suitable with Temkin, Freundlich, Dubinin-Radushkevich). From the two carbon particle sizes, the particle size of $250 \mu \mathrm{m}$ has good performance. The smaller-sized particles are optimal in the adsorption process because they can increase the adsorption capacity due to the larger surface area and the maximum adsorption capacity $\left(Q_{\max }\right)$ is $37.5940 \mathrm{mg} / \mathrm{g}$. Thus, this banana stem carbon has the potential to be used as an adsorbent in absorbing textile dye waste.

\section{ACKNOWLEDGEMENTS}

We would like to thank Universitas Pendidikan Indonesia for supporting this study. We acknowledged RISTEK BRIN (Grant: Penelitian Terapan Unggulan Perguruan Tinggi) and Bangdos Universitas Pendidikan Indonesia.

\section{REFERENCES}


Ab Ghani, Z., Yusoff, M. S., Zaman, N. Q., Zamri, M. F. M. A., \& Andas, J. 2017. Optimization of preparation conditions for activated carbon from banana pseudo-stem using response surface methodology on removal of color and COD from landfill leachate. Waste Management: 62: 177-187.

Ata, S., Tabassum, A., Bibi, I., Ghafoor, S., Ahad, A., Bhatti, M. A., \& Iqbal, M. 2019. Synthesis and characterization of $\mathrm{ZnO}$ nanorods as an adsorbent for $\mathrm{Cr}$ (VI) sequestration. Zeitschrift für Physikalische Chemie. 233(7): 995-1017.

Chung, H. K., Kim, W. H., Park, J., Cho, J., Jeong, T. Y., \& Park, P. K. 2015. Application of Langmuir and Freundlich Isotherms to predict adsorbate removal efficiency or required amount of adsorbent. Journal of Industrial and Engineering Chemistry. 28: 241-246.

Dada, A. O., Ojediran, J. O., Okunola, A. A., Dada, F. E., Lawal, A. I., Olalekan, A. P., \& Dada, O. 2019. Modeling of biosorption of $\mathrm{Pb}$ (II) and $\mathrm{Zn}$ (II) ions onto PAMRH: Langmuir, Freundlich, Temkin, Dubinin-Raduskevich, Jovanovic, Flory-Huggins, Fowler-Guggenheim, and Kiselev comparative isotherm studies. International Journal of Mechanical Engineering and Technology (IJMET). 10(2): 1048-1058.

Das, N., Karthika, P., Vimala, R., Vinodhini, V. 2008. Use of Natural Products as Biosorbent of Heavy Metals: An overview, Natural Product Radiance. 7(2): 133-138

Fiandini, M., Ragadhita, R., Nandiyanto, A. B. D., \& Nugraha, W. C. 2020. Adsorption characteristics of submicron porous carbon particles prepared from rice husk. Journal of Engineering Science and Technology. 15: 022-031.

Grace, O. C. A., Lloyd, G. A., \& Cornelius, W. 2020. Performance of Plantain Pseudo Stem for $\mathrm{Pb}$ Adsorption in Aqueous Solution. European Journal of Advances in Engineering and Technology. 7(4): 36-44.

Hayati, B., Maleki, A., Najafi, F., Gharibi, F., McKay, G., Gupta, V. K., \& Marzban, 
N. 2018. Heavy metal adsorption using PAMAM/CNT nanocomposite from aqueous solution in batch and continuous fixed bed systems. Chemical Engineering Journal. 346: 258-270.

Hu, Q., \& Zhang, Z. 2019. Application of Dubinin-Radushkevich isotherm model at the solid/solution interface: a theoretical analysis. Journal of Molecular Liquids. 277: 646648.

Kamga, F. T. 2019. Modeling adsorption mechanism of paraquat onto Ayous (Triplochiton scleroxylon) wood sawdust. Applied Water Science. 9(1): 1-7.

Lairini, S., El Mahtal, K., Miyah, Y., Tanji, K., Guissi, S., Boumchita, S., \& Zerrouq, F. 2017. The adsorption of Crystal violet from aqueous solution by using potato peels (Solanum tuberosum): equilibrium and kinetic studies. Journal Material. Environment. Science. 8(9): 3252-3261.

Langmuir, I. 1918. The adsorption of gases on plane surfaces of glass, mica, and platinum. Journal of the American Chemical Society. 40(9): 1361-1403.

Mahmoud, M. E., Amira, M. F., Seleim, S. M., \& Mohamed, A. K. 2017. Adsorption isotherm models, kinetics study, and thermodynamic parameters of $\mathrm{Ni}$ (II) and $\mathrm{Zn}$ (II) removal from water using the LbL technique. Journal of Chemical \& Engineering Data. 62(2): 839-850.

Meng, F., Zhang, X., Yu, W., \& Zhang, Y. 2019. Kinetic analysis of cellulose extraction from banana pseudo-stem by liquefaction in polyhydric alcohols. Industrial Crops and Products. 137: 377-385.

Mery, N., Al-Gifary, M., \& Walanda, D. K. 2019. Adsorption of Cd (II) By Carbon Prepared From Peels And Stems of Kepok Banana (Musa Paradisiaca Formatypica). Cellulose Chemistry and Technology. 53(3-4): 387-394.

Mishra, V., Balomajumder, C., \& Agarwal, V. K. 2010. Biosorption of Zn (II) onto the 
surface of non-living biomasses: a comparative study of adsorbent particle size and removal capacity of three different biomasses. Water, Air, \& Soil Pollution. 211(1): 489500.

Misran, E., Bani, O., Situmeang, E. M., \& Purba, A. S. 2021. Banana stem-based activated carbon as a low-cost adsorbent for methylene blue removal: Isotherm, kinetics, and reusability. Alexandria Engineering Journal 60: 1-10

Moelyaningrum, A. D., Zarkasi, K., \& Ningrum, P. T. 2018. Penggunaan arang aktif kulit durian (Durio Zibethinus Murr) Terhadap tingkat adsorpsi kromium (Cr6+) pada limbah batik. Efektor. 5(2): 67-73.

Nandiyanto, A. B. D., Arinalhaq, Z. F., Rahmadianti, S., Dewi, M. W., Rizky, Y. P. C., Maulidina, A., \& Yunas, J. 2020a. Curcumin Adsorption on Carbon Microparticles: Synthesis from Soursop (AnnonaMuricata L.) Peel Waste, Adsorption Isotherms and Thermodynamic and Adsorption Mechanism. International Journal of Nanoelectronics and Materials. 13: 173-192.

Ragadhita, R., Nandiyanto, A. B. D., Nugraha, W. C., \& Mudzakir, A. 2019. Adsorption Isotherm of mesopore-free submicron silica particles from rice husk. Journal of Engineering Science and Technology. 14(4): 2052-2062.

Ragadhita, R., \& Nandiyanto, A. B. D. 2021. How to calculate adsorption isotherms of particles using two-parameter monolayer adsorption models and equations. Indonesian Journal of Science and Technology, 6(1): 205-234.

Rahim, M., \& Haris, M. R. H. M. 2019. Chromium (VI) removal from neutral aqueous media using banana trunk fibers (BTF)-reinforced chitosan-based film, in comparison with BTF, chitosan, chitin, and activated carbon. Applied Sciences. 1(10): 1-11.

Wang, Y., Zhou, Y., Jiang, G., Chen, P., \& Chen, Z. 2020. One-step fabrication of carbonaceous adsorbent from corncob for enhancing adsorption capability of methylene 
blue removal. Scientific Reports. 10(1): 1-9.

Yaghoobi-Khankhajeh, S., Alizadeh, R., \& Zarghami, R. 2018. Adsorption modeling of CO2 in fluidized bed reactor. Chemical Engineering Research and Design. 129 111-121.

Yang, Z., Asoh, T. A., \& Uyama, H. 2019. Removal of cationic or anionic dyes from water using ion-exchange cellulose monoliths as adsorbents. Bulletin of the Chemical Society of Japan. 92(9): 1453-1461.

Zhou, L., Yu, Q., Cui, Y., Xie, F., Li, W., Li, Y., \& Chen, M. 2017. Adsorption properties of activated carbon from reed with a high adsorption capacity. Ecological Engineering. 102: 443-450. 